\title{
LONG-TERM DECLINE IN BREEDING ABUNDANCE OF BLACK-HEADED GULL (Chroicocephalus ridibundus) IN THE CZECH REPUBLIC: A CASE STUDY OF A POPULATION TREND AT THE CHOMOUTOV LAKE
}

\author{
KAREL POPRACH $^{1}$, IVO MACHAR $^{1^{*}}, \mathrm{KAREL} \mathrm{MATON}^{2}$ \\ ${ }^{1}$ Department of Development Studies, Faculty of Science, Palacký University, Olomouc, tř. 17. listopadu 12, 77140 \\ Olomouc, Czech Republic; e-mail: karel.poprach@tyto.cz, ivo.machar@upol.cz \\ ${ }^{2}$ Pod mlékárnou 608, 78314 Bohuňovice, Czech Republic; e-mail: karel@maton.cz \\ *Author for correspondence
}

\begin{abstract}
Poprach K., Machar I., Maton K.: Long-term decline in breeding abundance of Black-headed Gull (Chroicocephalus ridibundus) in the Czech Republic: a case study of a population trend at the Chomoutov lake. Ekológia (Bratislava), Vol. 35, No. 4, p. 350-358, 2016.
\end{abstract}

\begin{abstract}
The aim of this paper is to evaluate the long-term trend in breeding abundance of Black-headed Gull (Chroicocephalus ridibundus) at the Chomoutov lake, Czech Republic. In the period 1978-2014 (always between April 22 and May 10), we conducted 14 nest counts in the bird colony using the direct nest search method. In total, we counted 57,860 nests, from which 2,174 nests were found in the initial year 1978 , the maximum number of nests (8,371) in 1993 and 3,304 nests in the last counting year 2014. The nests were located on the ground on an island elevated 2-3 m above the water level. In 1997, we found an unusually located nest on a nesting pad in a poplar tree (Populus sp.), $821 \mathrm{~cm}$ above the water level. In this paper, we point out the long-term decline in breeding abundance of Black-headed Gull in major breeding colonies in the Czech Republic, where the abundance declined by up to $95 \%$, while numerous colonies have vanished completely. We discuss factors influencing the negative population trend of Black-headed Gull on the monitored site and in the entire Czech Republic.
\end{abstract}

Key words: Black-headed Gull, breeding population, trend, counting, Chomoutov lake, SPA Litovelské Pomoraví.

\section{Introduction}

The population of Black-headed Gull (Chroicocephalus ridibundus) in Europe with an estimated abundance over 1.5 million pairs was long considered stable (BirdLife International, 2004). Since the 1990s, however, a decrease in the numbers of breeding pairs on the local colonies is being observed (Tucker, Heath 1994; van Dijk et al., 2009). In the Czech Republic, the abundance of Black-headed Gull increased significantly after 1945, when some breeding colonies exceeded 10,000 breeding pairs (Martiško et al., 1994). Between the years 1973-1977, the breeding population reached its highest numbers, estimated to be 200,000-350,000 breeding 
pairs (Štastný et al., 1987). In the following years, the number of breeding pairs underwent a significant and yet unexplained decline (Štastný et al., 2006). This decline is being discussed by several studies, for example a decline in the Southern Bohemia discussed by Kloubec (2002), on the Nové Mlýny reservoirs by Chytil, Macháček (2000), on the ponds at Náměšt nad Oslavou by Fiala (1998), etc. For that reason, the severely declining species was added on the Red List of Birds of the Czech Republic (Štastný, Bejček, 2003), in the category “vulnerable species”.

The first occurrence and first nesting record of Black-headed Gull at the Chomoutov Lake are described by Rumler (1975). Drozdek (1986/1987) later carried out an ecoethological study of the Black-headed Gull breeding population. The main objective of our paper is to elaborate on the long-term population trend of the Black-headed Gull breeding population at this site in the context of the ongoing strong decline of this species in the Czech Republic.

\section{Study site}

The breeding colony of Black-headed Gull is located at the Chomoutov Lake (121 ha, 216-220 m above sea level, Fig. 1). The site is part of the Litovelské Pomoraví Protected Landscape Area and Special Protection Area. A dominant habitat is the open surface of one large and one small lake (55\% of the area), but at present are also open and dispersed habitats, two islands in the large lake, two islands in the small lake, littoral zones and restored wetlands with stands of common reed (Phragmites australis) and reedmace (Typha sp.), and three smaller hedges. From the hydrological point of view, the lake is a stagnant pond without a surface-water inflow and outflow, fed by ground water and, to a lesser extent, by precipitation (Poprach, 2003; Poprach et al., 2014).

The breeding colony of Black-headed Gull is located on the northern part of the large island, elevated 2-2.5 m above the water level. This is where $98 \%$ of all nests were located during our study $(49.6540575 \mathrm{~N}, 17.2379183 \mathrm{E})$. A smaller number of pairs were nesting on the small island $(49.6576467 \mathrm{~N}, 17.2391764 \mathrm{E})$ and isles in the spawning grounds (49.6537989N, 17.2423092E). In the assessed period of 1978-2014, the study site underwent hydrological

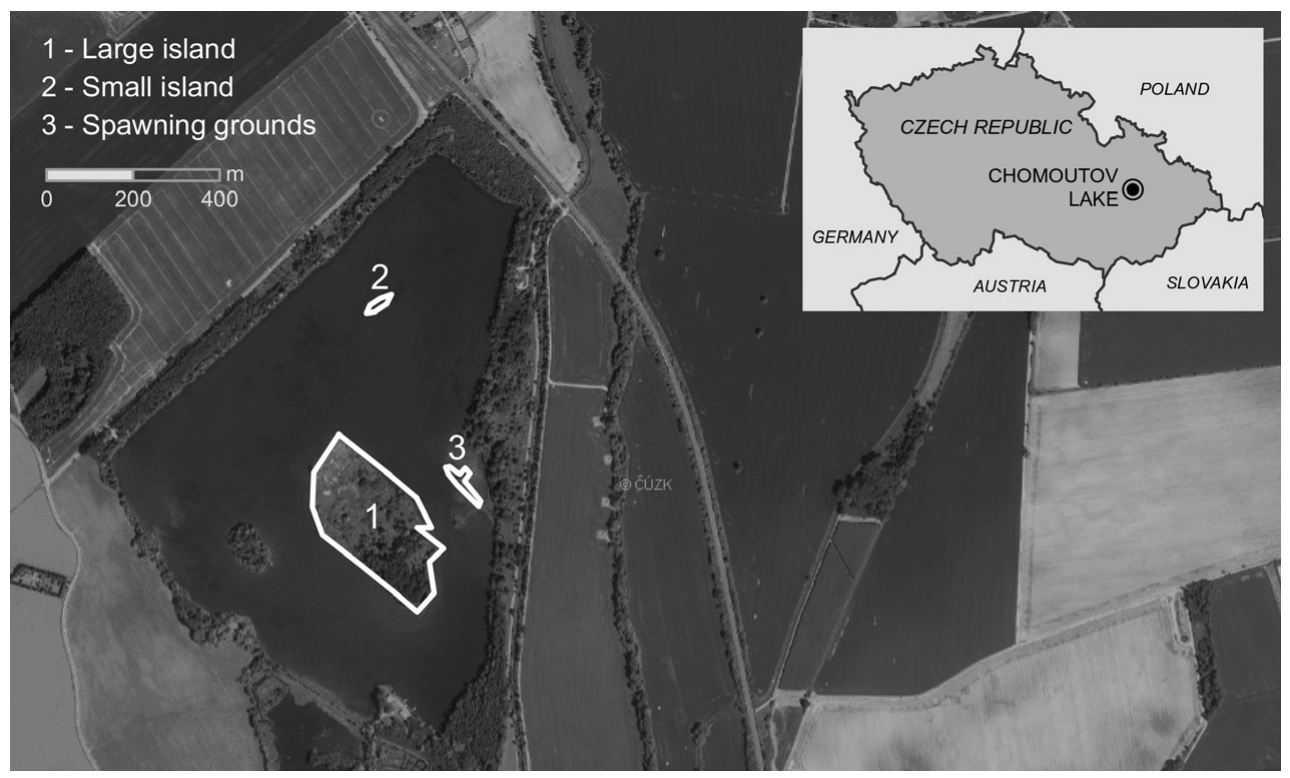

Fig. 1. Map of the Chomoutov Lake (aerial photograph, 2011). 
changes as a result of water level rise, which, given the location of Black-headed Gull nests on the islands, did not have a negative effect on the population. The dominant vegetation of the breeding colony on the large island consists of bushgrass (Calamagrostis epigejos), couch grass (Elytrigia repens), common rush (Juncus effusus), reed canary grass (Phalaris arundinacea), greater pond sedge (Carex riparia), common meadow-grass (Poa pratensis), common nettle (Urtica dioica), and, locally, of common cattail (Typha latifolia) and narrowleaf cattail (T. angustifolia).

\section{Methods and data processing}

In the period 1978-2014, we conducted a total of fourteen nest counts in the Black-headed Gull colony, always between April 22 and May 10 (Table 1). In this period, we assumed nesting for a majority of pairs. We counted all nests, including the empty ones. For those counts conducted in the last third of April, any late breeding pairs (who started nesting in May) were not included in the count data. We counted nests using the direct nest search method. In order to avoid duplicate records, we used paper tags, labeling each nest with one part of the tag, and using the second part to write down the nest status (number of eggs and chicks or empty nest). In the initial years, the nest counts were conducted by a group of three to six observers, and since 1993, when the number of breeding pairs increased, by a group of 15-20 observers. The intention was to count all nests in the colony within the shortest possible time. The observers moved in a compact shape and gradually walked through the entire colony. The gulls have become accustomed to the human presence and the majority of incubating individuals returned to their nests during the counting. The data were processed in MS Excel.

T a b le 1. Number of breeding pairs of Black-headed Gull (Chroicocephalus ridibundus) at the individual sites of Chomoutov lake in the period of 1978-2014.

\begin{tabular}{|l|c|c|c|c|}
\hline Date of bird count & Large island & Small island & Islands in the spawning grounds & Total \\
\hline 22 April 1978 & 2,174 & - & - & $\mathbf{2 , 1 7 4}$ \\
\hline 9 May 1979 & 1,440 & - & - & $\mathbf{1 , 4 4 0}$ \\
\hline 26 April 1980 & 1,107 & 144 & - & $\mathbf{1 , 2 5 1}$ \\
\hline 1 May 1981 & 2,163 & 192 & - & 2,355 \\
\hline 8 May 1982 & 2,932 & 195 & - & $\mathbf{3 , 1 2 7}$ \\
\hline 7 May 1983 & 2,764 & 85 & - & $\mathbf{2 , 8 4 9}$ \\
\hline 10 May 1985 & 3,435 & 105 & - & $\mathbf{3 , 5 4 0}$ \\
\hline 3 May 1986 & 3,875 & - & - & 3,875 \\
\hline 1 May 1993 & 8,371 & - & - & $\mathbf{8 , 3 7 1}$ \\
\hline 9 May 1998 & 8,012 & 7 & - & $\mathbf{8 , 0 1 9}$ \\
\hline 27 April 2001 & 6,873 & - & 218 & $\mathbf{7 , 0 9 1}$ \\
\hline 28 April 2007 & 5,819 & - & 200 & $\mathbf{6 , 0 1 9}$ \\
\hline 30 April 2011 & 4,445 & - & - & $\mathbf{4 , 4 4 5}$ \\
\hline 1 May 2014 & 3,304 & - & - & $\mathbf{3 , 3 0 4}$ \\
\hline Total & 56,714 & 728 & 418 & 57,860 \\
\hline
\end{tabular}

\section{Results}

The breeding colony of Black-headed Gull at the Chomoutov Lake formed in 1973. In 1974, it consisted of 300-400 breeding pairs (Rumler, 1975). Štěrba and Písek (1976) counted 300 nests in 1975, and already 3,000-5,000 in 1976. Between the years 1973 and 2014, the number of nests gradually increased to 8,371 by 1993 , then it stagnated and finally declined to 3,304 nests in 2014 (60\% decrease). 
In the period 1978-2014, we counted a total of 57,860 nests of Black-headed Gull on the site (Table 1, Fig. 2). Most nests (98\%) were located on the large island, in grassy vegetation. In 1978 , we counted 2,174 nests. Since 1981 , the colony slowly grew, reaching the maximum of 8,371 nests in 1993. Subsequently, the population went through a stagnation and decline, and the number of nests dropped to 3,304 by 2014. On May 24, 1997, we found an unusually located nest on the small island, situated on a nesting pad in a poplar tree (Populus sp.), 821 $\mathrm{cm}$ above water surface.

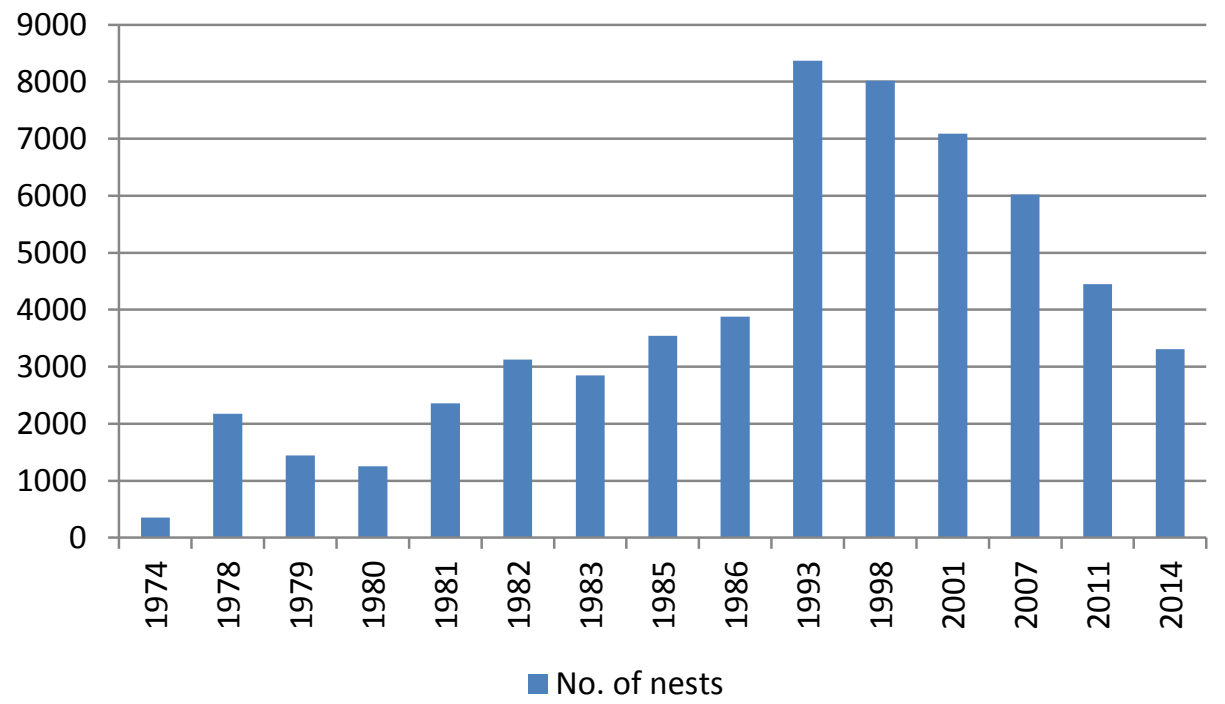

Fig. 2. Population trend of Black-headed Gull (Chroicocephalus ridibundus) at the Chomoutov Lake in the period 1978-2014.

\section{Discussion}

Population trend in the Black-headed Gull breeding population

Most sites in the Czech Republic experienced even more dramatic decline in breeding abundance of Black-headed Gull. The breeding peak in the Czech Republic occurred between the years 1973-1977. In these years, the population size was estimated to be 200,000-350,000 pairs (Hudec, Štastný, 2005), representing about 30\% of the Central European population (in contrast, both German republics had altogether a maximum $22 \%$ and the estimate for Slovakia was 4,000-5,000 pairs) (Glutz, Bauer, 1999). Subsequently, the population in the Czech Republic declined by $60 \%$ to 80,000-150,000 pairs between 1985 and 1989 (Hudec, Štastný, 2005), and then to 50,000-100,000 pairs between 2001 and 2003 (Štastný et al., 2006). Based on the data from the Czech Society for Ornithology gathered by Zdeněk Vermouzek (in litt. 2011), there was 
19,550 breeding pairs of Black-headed Gull in the Czech Republic in 2011 (in comparison with the period from 1973 to 1977 , this represents a decline by $90 \%$ ) and many colonies have vanished (Hudec, Štastný, 2005; Štastný et al., 2006). A strong decline in breeding abundance of Blackheaded Gull in the Southern Bohemia has been recorded since 1980s. Some of the large colonies have vanished completely; new colonies form rarely, and only as temporary breeding sites with fewer breeding pairs. In the period of 2012-2014, a mere 17 breeding colonies were known in the České Budějovice, Třeboň and Písek regions (Kloubec et al., 2015). This strong decline in breeding abundance of Black-headed Gull in 1980s in the Czech Republic was in contrast with a stable trend or increase in abundance of the species in some western European countries (Källender, Lebreton, 1997). Before 2006, a global census estimated the population of Black-headed Gull at $4,800,000-8,900,000$ individuals with an ongoing decline. (BirdLife International, 2016). The majority of Black-headed Gull colonies have between 11 and 100 pairs, and only a small number of colonies exceed 10,000 pairs (del Hoyo et al., 1996). The Czech Republic has experienced a strong and long-lasting steady decline in the number of breeding pairs in the last 30 years, which can be documented by two largest breeding colonies. The breeding population at the Nové Mlýny reservoirs (BV) was estimated at 30,000 pairs between 1973 and 1977 (Hudec, Štastný, 2005) and 20,000 pairs (or up to 50,000 pairs) between 1979 and 1981 (Hudec, 1984; Chytil, Macháček, 2000; Macháček et al., 2012). In the subsequent years, the population declined to 7,476 pairs in 2000 (Chytil, Macháček, 2000), and 4,225 pairs in 2004 (Štastný et al., 2006). In 2012, the number of breeding pairs dropped to 3,510 (Macháček et al., 2012), and then to 1,740 pairs in 2014 (Josef Chytil in litt. 2015). These values represent a decline of $96.5 \%$ when compared with the estimated maximum. Řžabinec, the largest breeding colony in the Southern Bohemia, had a minimum of 10,000 to several tens of thousands breeding pairs before 1985 (Kloubec, Švecová, 1990). Between 1998 and 2002, there were 1,500-3,000 breeding pairs (Kloubec, 2002), in 2013 only 300-400 pairs, and in 2014 mere 40 pairs, with a majority of nests being predated (Jiř́ Šebestian in verb.). In 2011, the largest breeding colony of Black-headed Gull in the Czech Republic was located at the Chomoutov Lake consisting of 4,445 nests, and 3,304 nests in 2014.

\section{Location of nests}

In the Czech Republic, the breeding colonies of Black-headed Gull are established predominantly in shallow parts of ponds, in littoral vegetation and, more recently, on artificial islands (Hudec, Štastný, 2005). The colony usually establishes at a certain core spot and then gradually extends around the perimeter; larger colonies can have several core spots (Klíma, 1964). The formation of these core spots in a breeding colony at a particular site is likely bound to the preferred types of vegetation used for building nests. After reaching a certain density of nests in the most preferred vegetation types, the density no longer increases and the area of a breeding site extends into less suitable vegetation (Drozdek, 1986/1987). While the distances between individual nests at the Chomoutov lake were tens of centimeters in the culmination years, the distances significantly increased (more than 1 meter) when the number of breeding pairs dropped and the entire colony size has decreased (Poprach unpubl.). On average, the distance between individual nests in the colonies is $1 \mathrm{~m}$ (del Hoyo et al., 1996), most often $70-100 \mathrm{~cm}$, but commonly also $30-50 \mathrm{~cm}$ (Glutz, Bauer, 1999). 
At the Chomoutov lake, nests were preferably built in the communities of common meadowgrass, couch grass and greater pond sedge, while the communities of reed canary grass, common rush and bushgrass, as well as common nettle, common tansy (Tanacetum vulgare) and common wormwood (Artemisia vulgaris) were neglected because of their height that complicates the orientation of incubating gulls in the nest proximity (Drozdek, 1986/1987). The ideal nesting environment is vegetation that provides an unblocked view of the surroundings but at the same time partially shields the view of nearest nests (Burger, 1976). Particularly in floodplain areas, Black-headed Gulls built their nests also on trees (Hudec, Štastný, 2005). For example, nests in the Dyje river floodplain in Southern Moravia were located $70-150 \mathrm{~cm}$ above water level on the willow trees (Folk, Hudec, 1964) and at the Chropyňský pond (Kroměříž district) the gulls nest in the black elder (Sambucus nigra) shrubs (Hudec, Štastný, 2005). There are known cases of nests located almost $9 \mathrm{~m}$ above ground on trees or buildings (Glutz, Bauer, 1999). We noticed an unusually placed nest at the Chomoutov Lake on a nesting pad in poplar tree (Populus sp.), $821 \mathrm{~cm}$ above the water surface, which makes it one of the highest placed Black-headed Gull nests in Europe.

In the Czech Republic, other colonial breeding birds are often associated with the breeding colonies of Black-headed Gull, e.g. black-necked grebe (Podiceps nigricollis) or common tern (Sterna hirundo) (Cepák, 2015; Hudec, Štastný, 2005). At the Chomoutov lake, such species are Mediterranean Gull (Ichthyaetus melanocephalus) with 3-17 pairs, mallard (Anas platyrhynchos) with 4-15 pairs and tufted duck (Aythya fuligula) with 1-5 pairs. Black-necked grebes have never nested at the site (Poprach et al., 2006, 2014). In 2014, we recorded a mixed pair of Black-headed Gull and Mediterranean Gull (a nest with one egg), but later on the breeding was shown to be unsuccessful (Poprach unpubl.).

\section{Causes of decline in breeding abundance of Black-headed Gull}

The dramatic decline in breeding abundance of Black-headed Gull at the Chomoutov Lake and in the Czech Republic cannot be attributed to a natural fluctuation in the population size. Some direct anthropogenic factors (removal of pond sediments, fluctuations in water level, removal of suitable nesting vegetation, livestock grazing, recreational water activities, game management) have persisted for decades and therefore it is unlikely that they would significantly contribute to the decline of the Black-headed Gull population (Kloubec, Švecová, 1990). These authors also include collection of eggs among the above listed anthropogenic factors, but this activity does not have a significant impact any longer. In 1976, Štěrba, Písek (1976) proposed a targeted eradication of the growing Black-headed Gull colony at the Chomoutov Lake for epidemiological reasons by disturbing gulls before their breeding season or by collecting their eggs and destroying the nests (Štěrba, 1977). In 1978, most of the eggs were destroyed just before hatching (Štěrba, 1978). In 1979, there was a suggestion to install a ferry for fishermen in order to destroy the colony on the island (Štěrba, 1979). In the same year, members of a hunting association have removed eggs from two-thirds of the clutches, which resulted in a reduced number of counted nests $(1,440)$. The egg removal likely caused a decline in the number of breeding pairs in the following year (own results). The Black-headed Gulls were blamed for negative environmental and economic impacts, such as consumption of fish (on the site) and pheasant chicks (in the pheasantries in the Litovelské Pomoraví), deterioration of water quality in the lake and its eutrophication (sources of drinking 
water). The last attempt to destroy the colony was conducted in 1983 (Drozdek, 1986/1987). Since 1983, after the termination of these destructive attempts, the colony has significantly grown in numbers. According to Drozdek (1986/1987), who studied nitrate levels at the Chomoutov Lake during May and June, gulls did not significantly affect nitrate levels in the lake; some nitrogen compounds remained bound in the soil of the large island and some were utilised by phytoplankton in the water.

Breeding sites on isolated landfills and islands, which predominate in Southern Bohemia, are relatively safe for the breeding birds and spared from significant predator pressure (Kloubec, Švecová, 1990). However, this is only true for certain terrestrial native predator species. On the other hand, breeding sites accessible for predators can be under significant predation pressure. The Rzy wetland (Ústí nad Orlicí district) underwent a marked decline in the number of breeding pairs of Black-headed Gull in the years with a precipitation deficit, because the littoral zones dried out and the nests were exposed to wild boar (Sus scrofa) predation (Martin Fejfar in litt. 2013). It is noteworthy that in 2011 there was 17 breeding pairs of Mediterranean Gull at the Chomoutov Lake (Poprach et al., 2014) but not a single chick was fledged. Although the breeding colony of Black-headed Gull is able to actively defend the breeding site against predators during the day, defense against nocturnal predators is difficult. Predation by geographically nonnative predators - racoon dog (Nyctereutes procyonoides) and raccoon (Procyon lotor), which are both present and reproduce in Central Moravia - cannot be ruled out on islands.

Kloubec, Švecová (1990) consider intoxication by foreign substances with subsequent reduced birthrate and increased mortality of juveniles and adults as the most important factor contributing to the decline of Black-headed Gull breeding populations. Based on the data collected in colonies around České Budějovice, the authors noticed a relatively low average clutch size (2.3 eggs per nest) and detected an egg contamination by DDE and PCB. At the Chomoutov Lake, the average number of eggs/chicks ranged between 2.2 and 2.6, and we did not see a negative trend in the chronological development of the average values. These values have rather fluctuated in individual years (Poprach unpubl.). The sharp decline in Black-headed Gull population in the Czech Republic correlates with the decline of Black-necked grebe. For both species, a decreased water transparency and thus limited opportunities for feeding on aquatic invertebrates can have a certain negative effect (Cepák, 2015).

In 2010, about 1,440 dead individuals of Black-headed Gull were recorded at the Chomoutov Lake. The dissection of eight dead individuals showed intoxication by bromadiolone (an active substance of the Lanirat ${ }^{\circledast}$ MICRO rodenticide). The first symptoms of poisoning were observed on April 8, and massive poisoning manifested over the next few days, with birds dying directly in their nests. Almost certainly, this situation was caused by a primary intoxication as a result of direct ingestion of the Lanirat ${ }^{\circledast}$ MICRO rodenticide, which was applied by three agricultural enterprises in close proximity (100-7,000 m) of the breeding site. The Czech Environmental Inspectorate subsequently issued an interim measure forbidding the use of Lanirat ${ }^{\circledast}$ MICRO within a $10 \mathrm{~km}$ radius around the breeding site (i.e. within an estimated flight range of Black-headed Gull when searching for food). During each visit of the breeding colony at the Chomoutov Lake, it was possible to find some dead adult individuals in different parts of the site. On 7 May 2008, we recorded six dead adult individuals next to some regurgitated spring barley (Hordeum vulgare), which was likely consumed by the gulls at the nearby field. These findings indicate that intoxica- 
tion (both primary - ingestion of rodenticide or chemically treated seeds - and secondary - ingestion of chemically treated plants or contaminated animals) of Black-headed Gulls as a result of food foraging in agrarian landscapes - can have a significant negative effect on their population (Poprach, 2010).

Källender, Lebreton (1997) discuss a decline in breeding abundance of Black-headed Gull in Latvia from 110,000 pairs in 1986 to 40,000 in 1994, likely as a result of limited food availability. Negative factors influencing the Black-headed Gull population listed by the authors include high temperatures and drought late in the breeding season, causing limited access to earthworms for chicks, fluctuations of water levels, predation and disturbance at the breeding sites. Del Hoyo et al. (1996) point out that some breeding sites are abandoned due to overgrowing vegetation. Research in larger breeding colonies (colonies of 10-5,000 pairs were studied) revealed a negative effect of colonial breeding in the first days of life of new chicks, but this effect is later compensated by a higher proportion of all surviving chicks. Total losses occurring in breeding colonies thus increase with decreasing number of breeding pairs (Peron et al., 2010). In Netherlands and Belgium, it was found out that the inland breeding colonies have lower breeding success when compared with the colonies at the North Sea coast. The inland colonies had lower average number of eggs (2.4 vs. 2.7), lower hatchling success rate (48 vs. $73 \%$ ) and lower overall breeding success (0.4 fledglings/pair vs. 0.9). Both colony types produce less than one chick per breeding pair, which is the minimum required for maintaining a stable population. The results show that the main factor contributing to the decline of Black-headed Gull population in the Netherlands (especially in the inland colonies) is predation of eggs rather than a lack of food resources during fledging (van Dijk et al., 2009). From a longer term point of view, it is important that the chicks return to their breeding sites later in their life (del Hoyo et al., 1996). It is likely that the breeding population of Black-headed Gull is affected by a set of negative factors that may be specific to individual sites and regions.

\section{Acknowledgements}

We thank our colleagues and all volunteers who participated in the nest surveys at the Chomoutov Lake during the individual monitoring years. Fourteen surveys carried out during 37 years of monitoring involved about 200 field workers. In the initial years, the nest counts were conducted by small groups of observers, and, since 1993, by 15-20 observers. We thank Jaroslav Spurný, who turned 75 during the field survey in 2014, for his help in the field. We thank our colleagues Aleš Poprach, Jiří Lehký, Petr Loyka and Roman Slavíček, who helped with processing and tabulating of the survey data. We thank Zdeněk Vermouzek and members of the Czech Society for Ornithology for providing unpublished data on the abundance of breeding populations of Black-headed Gull in the Czech Republic in 2011. We thank Josef Chytil and Jiři Šebestian for providing their own unpublished data from the Nové Mlýny reservoirs and the Režabinec site.

\section{References}

BirdLife International (2004). Birds in Europe: Population estimates, trends and conservation status. BirdLife Conservation Series No.12. Cambridge: BirdLife International.

BirdLife International (2016). Species factsheet: Larus ridibundus. Downloaded from http://www.birdlife.org on 28/07/2016.

Burger, J. (1976). Nest density of Black-headed Gull in relation to vegetation. Bird Study, 23, 27-32.

Cepák, J. (2015). Bird of the year introduced (in Czech). Ptačí Svět, 1, 3-8.

del Hoyo, J., Elliott, A. \& Sargatal J. (Eds.) (1996). Handbook of the birds of the World. Vol. 3. Hoatzin to Auks. Barcelona: 
Lynx Edicions.

van Dijk, J.G.B., Stienen, E.W.M., Gerritsen, S. \& Majoor F.A. (2009). Reproductie van de Kokmeeuw Larus ridibundus in kusten binnenlandkolonies. Limosa, 82, 13-22.

Drozdek, K. (1986/1987). An eco-ethological study of Black-headed Gull (Larus ridibundus L.) at the ponds in Poodři and Chomoutov Lake near Olomouc (in Czech). Master's thesis, Faculty of Science, Palacký University Olomouc.

Fiala, V. (1998). Changes in avifauna of Náměšt ponds in the period 1885-1997 (in Czech). Zprávy MOS, 56, 99-119.

Folk, Č. \& Hudec K. (1964). Other breeding sites of Night Heron (Nycticorax nycticorax), Greylag Goose (Anser anser) and Black-headed Gull (Larus ridibundus) in southern Moravia (in Czech). Zoologické Listy, 13, 175-177.

Glutz von Blotzheim, U.N. \& Bauer K.M. (1999). Handbuch der Vögel Mitteleuropas. Band 8/I. Charadriiformes (3. Teil). Vogelzug-Verlag um Humanitas Buchverstand. AULA-Verlag GmbH.

Hudec, K. (1984). Nové Mlýny reservoir and fauna of Podyjí (in Czech). Živa, 32, 156-157.

Hudec, K. \& Štastný K. (Eds.) (2005). Birds 2/II (in Czech). Praha: Academia.

Chytil, J. \& Macháček P. (2000). Development of breeding population of Laridae and Sternidae in the southernmost Moravia (in Czech). Sylvia, 36,113-126.

Källender, H. \& Lebreton J.D. (1997). Black-headed Gull (Larus ridibundus). In E.J.M., Hagemeijer \& M.J. Blair (Eds.), The EBCC Atlas of European Breeding Birds: Their Distribution and Abundance (pp. 328-329). London: T \& D Poysor.

Klíma, M. (1964). Contribution to the breeding biology of the Black-headed Gull (Larus ridibundus L.). Zoologické Listy, 13,111-124.

Kloubec, B. \& Švecová Z. (1990). Changes in the South Bohemian population of Black-headed Gull (Larus ridibundus) and their possible causes (in Czech). In Ptáci v kulturní krajině (pp. 119-140). 1. díl. Proceedings of the II. South Bohemian Ornithological Conference held on February 25 and 26, 1989 in České Budějovice.

Kloubec, B. (2002). Abundance of the South Bohemian population of Black-headed Gull (Larus ridibundus) in the period 1998-2002 (in Czech). Sylvia, 38, 75-82.

Kloubec, B., Hora, J. \& Štastný K. (Eds.) (2015). Ptáci jižních Čech. Jihočeský kraj, České Budějovice.

Macháček, P., Chytil, J. \& Šebela M. (2012). Birds of the Nové Mlýny reservoir (in Czech). Regionální muzeum v Mikulově, Muzeum Komenského v Přerově \& Moravské zemské muzeum Brno.

Martiško, J., Štastný, K., Bejček, V., Hudec, K., Pellantová, J. \& Vlašín M. (1994). Distribution of nesting birds. South Moravia. Part 1. Non-songbirds (in Czech). Brno: Moravské zemské muzeum, ČSOP ZO Pálava.

Peron, G., Lebreton, J.D. \& Crochet P.A. (2010). Costs and benefits of colony size vary during the breeding cycle in Black-headed Gulls. Journal of Ornithology, 151, 881-888.

Poprach, K. (2003). Management plan for the Chomoutov lake nature reserve and its protection zone in the period 20042013 (in Czech). Litovel: Správa chráněné krajinné oblasti Litovelské Pomoraví.

Poprach, K., Chytil, J. \& Haluzík M. (2006). Distribution and abundance of breeding population of Mediterranean Gull (Larus melanocephalus) in the Czech Republic (in Czech). Sylvia, 42, 66-80.

Poprach, K. (2010). Catastrophic mortality of Black-headed Gull (in Czech). Ochrana Přirody, 6, 30-31.

Poprach, K., Maton, K. \& Machar I. (2014). Nesting bird communities of the Chomoutov lake natural monument (in Czech). Zprávy MOS, 72, 4-28.

Rumler, Z. (1975). Notes on the presence of birds on certain localities of Moravia and Slovakia during the breeding period of 1974 (in Czech). Zprávy Vlastivědného Ústavu v Olomouci, 175, 22-32.

Štastný, K., Randík, A. \& Hudec K. (1987). Atlas of nesting birds in Czechoslovakia 1973/77 (in Czech). Praha: Academia.

Štastný, K. \& Bejček V. (2003). Red list of birds in the Czech Republic. Př́roda (Praha), 22, 95-110.

Štastný, K., Bejček, V. \& Hudec K. (2006). Atlas of nesting birds in the Czech Republic 2001-2003 (in Czech). Praha: Aventinum.

Štěrba, O. \& Písek J. (1976). Research report on the waterworks gravel site at Chomoutov in 1976 (in Czech). Ms., dep. Správa CHKO Litovelské Pomoraví.

Štěrba, O. (1977). Biological organisms and water quality of the Chomoutov gravel site in 1977 (in Czech). Ms., dep. Správa CHKO Litovelské Pomoraví.

Štěrba, O. (1978). Biological organisms and water quality of the Chomoutov gravel site in 1978 (in Czech). Ms., dep. Správa CHKO Litovelské Pomoraví.

Štěrba, O. (1979). Biological organisms and water quality of the Chomoutov gravel site in 1979 (in Czech). Ms., dep. Správa CHKO Litovelské Pomoraví.

Tucker, G.M. \& Heath M.F. (1994). Birds in Europe: Their Conservation Status. BirdLife Conservation Series No. 3. Cambridge: BirdLife International. 